\title{
Inhibition effect of silver nanoparticles on herpes simplex virus 2
}

\author{
R.L. Hu, S.R. Li, F.J. Kong, R.J. Hou, X.L. Guan and F. Guo \\ Department of Obstetrics and Gynecology, \\ The First Affiliated Hospital of Xinxiang Medical University, \\ Weihui, Henan Province, China \\ Corresponding author: R.L. Hu \\ E-mail: ruilihu@126.com \\ Genet. Mol. Res. 13 (3): $7022-7028$ (2014) \\ Received May 22, 2013 \\ Accepted September 20, 2013 \\ Published March 19, 2014 \\ DOI http://dx.doi.org/10.4238/2014.March.19.2
}

\begin{abstract}
The herpes simplex virus 2 (HSV-2) is one of the most important sexually transmitted pathogens, and can facilitate the spread of human immunodeficiency virus. The currently available antiviral drugs have certain limitations. Nanosilver has received increasing attention recently with respect to its antibacterial and antiviral properties. The purpose of this study was to determine the inhibiting effect and mechanism of silver nanoparticles (Ag-NPs) on HSV-2. The cytotoxicity of Vero cells induced by different AgNP concentrations was investigated by using the methyl thiazolyl tetrazolium (MTT) assay. The inhibiting effect of Ag-NPs on HSV2 at various times was also evaluated by using a plaque assay. The toxicity of $100 \mu \mathrm{g} / \mathrm{mL}$ Ag-NPs on Vero cells was very low. The mixture of Ag-NP suspension and HSV-2 prior to infecting cells could significantly inhibit the production of progeny viruses. AgNPs also inhibited the replication of HSV-2 for $24 \mathrm{~h}$ before infecting cells with HSV-2. Therefore, $100 \mu \mathrm{g} / \mathrm{mL}$ Ag-NPs could completely inhibit HSV-2 replication. Ag-NPs at nontoxic concentrations were capable of inhibiting HSV-2 replication when administered prior to viral infection or soon after initial virus exposure. This suggests
\end{abstract}


that the mode of action of Ag-Nps occurs during the early phases of viral replication.

Key words: Silver nanoparticles; Herpes simplex virus 2; Antiviral therapy

\section{INTRODUCTION}

Herpes simplex virus 2 (HSV-2) is a type of a virus that can cause a global burden (Looker et al., 2008), and the presence of herpetic infection can significantly increase an individual's chances of becoming infected with human immunodeficiency virus (HIV)-1 (Freeman et al., 2006). Despite the widespread use of antiviral therapy in the past 20 years, the incidence of infection and complications caused by HSV-2 remain almost intact (Xu et al., 2006; Morris et al., 2008). Daily antiviral therapy has been shown to reduce genital injury (Mertz et al., 1988; Reitano et al., 1998) and to suppress the detection of HSV on the genital mucosa surface (Wald et al., 1996; Gupta et al., 2004). However, daily intake of acyclovir could only reduce the chance of sexually transmitted disease contamination by $48 \%$ (Corey et al., 2004). Furthermore, acyclovir is not effective in reducing an individual's chance of being infected with HIV or HSV-2 (Watson-Jones et al., 2008; Celum et al., 2008, 2010). However, the mechanism of clinical symptom suppression, as well as the reason for the failure to prevent HIV and HSV-2 infections, are not yet fully understood.

Current nanotechnology provides the possibility to produce new nanostructural materials, often in the $100 \mathrm{~nm}$ range or less, with surface modification and structural characteristics conferring biological activity and protein binding potential (Bender et al., 1996; Sondi et al., 2003; Ashammakhi, 2006). The use of silver nanoparticles (Ag-NPs) in biology has attracted great attention. Recently, an inexpensive method was introduced for the effective preparation of highly concentrated and nontoxic Ag-NPs with antibacterial properties (Sondi and SalopekSondi, 2004). The interaction between nanoparticles and microorganisms is a subject of intensive research; however, studies on the interaction of nanosilver and viruses are gradually decreasing despite the success of recent studies showing that nanosilver could inhibit HIV-1 (Rogers et al., 2008) and monkeypox virus (Schrand et al., 2008). The aim of this study was to determine the inhibiting effect and mechanism of Ag-NPs on HSV-2.

\section{MATERIAL AND METHODS}

\section{Experimental materials}

Nano Silver-PVP (0.2 wt\% PVP; 30-40 nm particle size) was purchased from Shenzhen Baiwang Biological Science and Technology Ltd. (Shenzhen, China). Dulbecco's modified Eagle's medium (DMEM), pancreatin, penicillin, and streptomycin were purchased from the Gibco BRL company (Grand Island, NY, USA). Methyl thiazolyl tetrazolium (MTT), crystal violet, and Trypan blue were purchased from Sigma-Alrich (San Francisco, CA, USA). Acyclovir was produced by Xi' an Jiahe Pharmaceutical Ltd. (Xi'an, China). African green monkey kidney cells (Vero cells) were provided by the China Center for Type Culture Collection (Beijing, China). HSV-2 (No. 333) was generously donated by Dr. Gong Zhenkui, Disease Control Center of Hubei Province, China. The viruses were stored at $-70^{\circ} \mathrm{C}$. The 
study was approved by the Ethics Committee of the First Affiliated Hospital of Xinxiang Medical University, China.

Vero cells were cultured in DMEM containing 10\% fetal calf serum (Hyclone, Logan, UT, USA), $100 \mathrm{IU} / \mathrm{mL}$ penicillin, and $100 \mu \mathrm{g} / \mathrm{mL}$ streptomycin in an incubator with $5 \% \mathrm{CO}_{2}$ at $37^{\circ} \mathrm{C}$. The cells were passaged once every 1 to 2 days. HSV was used to infect Vero cells for proliferation, and the $50 \%$ cell culture infective dose $\left(\mathrm{CCID}_{50}\right)$ and the Reed-Muench formula were used to determine the viral titer.

\section{MTT assay}

One hundred microliters of $2 \times 10^{3}$ Vero cells $/ \mathrm{mL}$ was seeded on 96-well plates. After culturing in a $5 \% \mathrm{CO}_{2}$ incubator for $12 \mathrm{~h}$ at $37^{\circ} \mathrm{C}$, the following nanosilver solution concentrations were respectively added: $6.25,12.5,25,50,100$, and $200 \mu \mathrm{g} / \mathrm{mL}$. The cells were further incubated for $48 \mathrm{~h}$, and their viability was measured by using the MTT assay. Another nanosilver group was established with a constant concentration, and observations continued for $96 \mathrm{~h}$ in order to detect whether or not an extended nanosilver action time was toxic to Vero cells. The inhibition of cell growth by nanosilver particles was calculated using the following formula:

$$
\text { inhibition rate }(\%)=\left(\text { optical density }(\mathrm{OD})_{\text {control group }}-\mathrm{OD}_{\text {administration group }} / \mathrm{OD}_{\text {control group }}\right) \times 100 .
$$

\section{Trypan blue assay}

Cells were plated as described above. After incubation for $12 \mathrm{~h}$ at $37^{\circ} \mathrm{C}$ and $5 \% \mathrm{CO}_{2}$, the nanosilver solutions were added at different concentrations and the incubation continued for another $48 \mathrm{~h}$. The cells were further digested with trypsin, and were stained with Trypan blue dye. The number of living cells was measured by using a hemocytometer and counted per 200 cells. The proportion of living cells was estimated, thereby calculating the inhibition rate of nanosilver on cell growth, to determine the $50 \%$ cytotoxic concentration of nanosilver.

\section{Nanosilver treatment}

Ag-NPs were diluted in DMEM and dispersed with ultrasound. HSV-2 was diluted at 1:40 ( $5 \times 10^{4} 50 \%$ tissue culture infective dose $\left./ \mathrm{mL}\right)$, and then added to the Ag-NP/DMEM mixture. The mixture was subsequently rotated and incubated for $1 \mathrm{~h}$ at room temperature, and finally added into the pre-inoculated Vero cells at $90 \%$ confluence. The cells were left to absorb the viral suspension for $1 \mathrm{~h}$, and non-absorbed viruses were subsequently removed by washing the cells in phosphate-buffered saline. Fresh complete DMEM was then added, and the cells were further cultured and observed daily for the cytopathic effect.

\section{Viral suppression experiments}

Vero cells were exposed to the different concentrations of Ag-NPs by the technique described above. After culturing for 6 days, the progeny viruses were collected from the infected supernatant by centrifuging at $580 \mathrm{~g}$. The mixture was subsequently centrifuged for 15 
min to remove cell debris. The virus titers were quantified by the TCID method.

\section{Statistical analysis}

Data were analyzed using SPSS 11.0 (SPSS Inc.; Chicago, IL, USA) and are reported as means \pm SE. $\mathrm{P}<0.05$ was considered to indicate a statistically significant difference.

\section{RESULTS}

\section{Ag-NP cytotoxicity test}

MTT assay and Trypan blue staining were used to measure the toxicity level of Ag-NPs. The Trypan blue-staining test showed that at the $200 \mu \mathrm{g} / \mathrm{mL}$ Ag-NP concentration, the Vero cell survival rate was above $90 \%$ (Table 1). The MTT tests also showed that Vero cells could maintain more than $90 \%$ activity at $200 \mu \mathrm{g} / \mathrm{mL}$ Ag-NPs. Both the Trypan blue staining and MTT tests showed that the $100 \mu \mathrm{g} / \mathrm{mL}$ Ag-NP concentration was not toxic to Vero cells.

Table 1. Effect of GLP in vitro on Vero cell proliferative activity by the Trypan blue detection.
\begin{tabular}{lcccc}
\hline Ag-NP concentration $(\mu \mathrm{g} / \mathrm{mL})$ & Detecting cell number & Viable cell number & Dead cell number & Cell survival rate (\%) \\
\hline 6.25 & 400 & 393 & 7 & 98 \\
12.5 & 400 & 385 & 15 & 96 \\
25 & 400 & 389 & 11 & 97 \\
50 & 400 & 383 & 17 & 96 \\
100 & 400 & 392 & 8 & 96 \\
200 & 400 & 380 & 20 & 90 \\
\hline
\end{tabular}

\section{Inhibitory action of Ag-NPs on the cytopathic effect}

Ag-NPs were found to inhibit the HSV-2-induced cytopathic effect on cells, and its half-maximal effective concentration was $25 \mu \mathrm{g} / \mathrm{mL}$ (Table 2). After being infected by HSV-2 for $48 \mathrm{~h}$, there was an obvious cytopathic effect observed on Vero cells, and their morphology changed significantly, resulting in rounding of the cell outline, wrinkled cell walls, and loss of contact between cells by separation (Figure 1A). By contrast, the morphology of the cells incubated with Ag-NPs remained unchanged (Figure 1B). The selectivity index of the inhibition of HSV-2 by Ag-NPs was 35.55 (Table 2).

\begin{tabular}{|c|c|c|c|c|}
\hline \multirow[t]{2}{*}{ Antiherpetic substances } & \multirow[t]{2}{*}{ Host cells } & \multirow[t]{2}{*}{$\mathrm{CC}_{50}(\mu \mathrm{g} / \mathrm{mL})$} & $\mathrm{EC}_{50}(\mu \mathrm{g} / \mathrm{mL})$ & $\mathrm{SI}\left(\mathrm{CC}_{50} / \mathrm{EC}_{50}\right)$ \\
\hline & & & HSV-2 & HSV-2 \\
\hline Ag-NPs & Vero & $>100$ & 25 & $>4.0$ \\
\hline Acyclovir & Vero & 819 & 2.0 & 409.50 \\
\hline
\end{tabular}




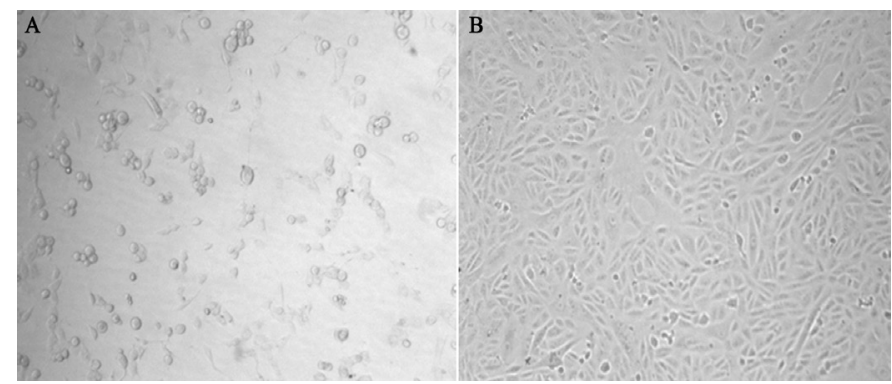

Figure 1. A. Vero cells infected with HSV-2; B. Vero cells infected with HSV-2, virus pre-treated with Ag-NPs.

\section{$\mathrm{CCID}_{50}$ detection of Ag-NP anti-viral activity}

The Ag-NPs showed strong inhibition of HSV-2 replication, especially when they were incubated with the virus for $1 \mathrm{~h}$ prior to infecting Vero cells. Moreover, when Ag-NPs and viruses were simultaneously added to the cells, lower inhibitory activity was observed. Although the lowest anti-viral activity was observed when Ag-NPs were added to virus-infected cells, the activity could still be suppressed within the first $24 \mathrm{~h}$ after infection, whereas after $24 \mathrm{~h}$ of infection, the inhibition was no longer obvious. Regardless of the manner in which Ag-NPs were added, when the Ag-NP concentration reached $100 \mu \mathrm{g} / \mathrm{mL}$, they could almost completely inhibit virus infection on Vero cells (Figure 2).

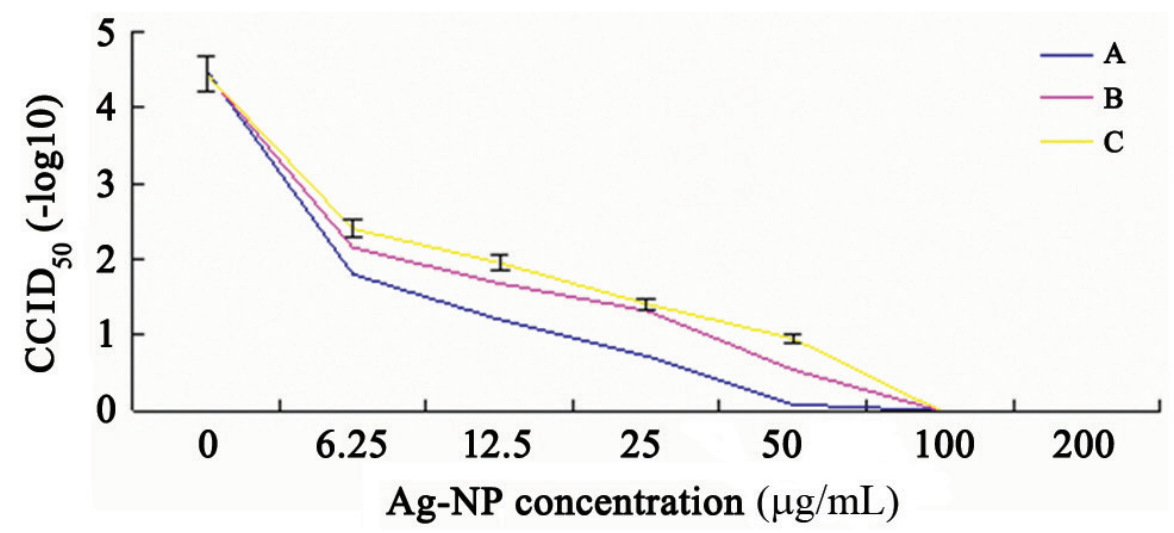

Figure 2. Effect of increasing concentration of Ag-NPs on the titer of HSV-2 in infected Vero cells by $\mathrm{CCID}_{50}$ assay. The multiplicity of infection was 0.1. Ag-NP was present in before (A), during (B) and after (C) HSV infection. The data are reported on the horizontal axis in $\log 10$ units as means \pm SD of at least three independent experiments.

Figure 2 shows that when viruses were incubated with different Ag-NP concentrations for $1 \mathrm{~h}$ before Vero cells were infected with HSV-1, the $\mathrm{CCID}_{50}$ of the virus reduced from $10^{4.5}$ cells per $0.1 \mathrm{~mL}$ to $10^{1.8}$ per $0.1 \mathrm{~mL}$, and the inhibition rate of viral replication reached $60 \%$. With increasing Ag-NP concentration, the inhibitory effect on HSV-2 became increasingly more prominent. The inhibition rate on HSV-2 reached up to $100 \%$ when the Ag-NP concentration reached $100 \mu \mathrm{g} / \mathrm{mL}$, i.e., HSV-2 replication was completely inhibited. Similarly, if the Ag-NPs and virus were added to the Vero cells simultaneously, GLP showed a similar inhibi- 
tory effect and curve as observed when Ag-NPs were added after virus incubation. In order to evaluate the inhibitory activity of the Ag-NPs after virus adsorption into cells, we also added Ag-NPs after the HSV-2 infection had adsorbed into Vero cells for $2 \mathrm{~h}$. As shown in Figure 2, when the Ag-NP concentration was $<100 \mu \mathrm{g} / \mathrm{mL}$, the inhibitory effect on viral infection was much weaker than that observed during pre-infection or infection with simultaneous administration. However, when the Ag-NP concentration reached $100 \mu \mathrm{g} / \mathrm{mL}$, it could completely inhibit the replication of HSV-2.

\section{DISCUSSION}

The present study was designed to evaluate the interaction between nanosilver and HSV-2 in order to determine whether nanosilver could cause a significant reduction of progeny viruses with weak cytotoxicity. Our findings indicated that although a $100 \mu \mathrm{g} / \mathrm{mL}$ or higher Ag-NP concentration was toxic to Vero cells (Table 1), 50 and $25 \mathrm{mg} / \mathrm{mL}$ Ag-NPs could significantly inhibit the generation of HSV-2 progeny (Figure 2). Even at a lower concentration, such as $6.25 \mu \mathrm{g} / \mathrm{mL}$, nanosilver showed a significant inhibiting effect on the titer of progeny virus. At a higher concentration, such as $100 \mu \mathrm{g} / \mathrm{mL}$, nanosilver had more significant toxic effects on Vero cells. As shown in the present study and in other reports, coating cells with polysaccharides or other materials can effectively protect cells from the toxicity of Ag-NPs. However, such coating also significantly affects the interaction between Ag-NPs and HSV-2. The Ag-NPs, regardless of being coated with polysaccharides, have a limited toxic effect on Vero cells. Virus replication was inhibited at $100 \mu \mathrm{g} / \mathrm{mL} \mathrm{Ag-NPs,} \mathrm{while} \mathrm{the} \mathrm{virus} \mathrm{progeny} \mathrm{was}$ significantly reduced at $6.25 \mu \mathrm{g} / \mathrm{mL} \mathrm{Ag-NPs}$.

A previous study demonstrated that Ag-NPs preferentially combined with the glycoprotein gp120 of HIV (Elechiguerra et al., 2005). In the present study, the Ag-NPs may have formed bonds with a glycoprotein membrane of HSV-2 that contains a sulfhydryl group, which can strongly interact with Ag-NPs. This interaction may prevent internalization of the virus by inhibiting the interaction between the glycoprotein and a receptor. Cellular uptake of AgNPs occurs mainly through clathrin-mediated endocytosis and macropinocytosis (Asharani et al., 2009). The cellular uptake of HSV-2 and other herpes viruses through clathrin-mediated endocytosis can be achieved by interactions with cell receptors. The similar mechanism of intracellular internalization further shows the possibility of intracellular interactions.

HSV-2 infection can easily cause ulceration of the genital tract, thus facilitating the spread of HIV and other sexually transmitted diseases. One of the drugs used to treat vaginal infections is nonoxynol-9, which can inactivate viruses through the destruction of the viral envelope protein. However, nonoxynol-9 is a kind of surfactant that damages vaginal epithelial cells, causing vaginal dysbacteriosis, and facilitating the spread of diseases such as HIV. Short interfering RNA inhibitors and other mucosal microbial drugs have not yet been launched on the market because they degrade easily and have toxic effects (Katakowski and Palliser, 2010). In China, India, and other countries, silver and silver derivatives are often used in traditional medicine as antibacterial and antiviral preparations, for example the widely used silver sulfadiazine is a nanosilver preparation. In the present study, we used the MTT method to show that Ag-NPs at concentrations less than $100 \mu \mathrm{g} / \mathrm{mL}$ have very limited toxicity to cells while inhibiting the replication of HSV-2. Therefore, nanosilver is a promising drug for use against sexually transmitted diseases. 


\section{REFERENCES}

Ashammakhi N (2006). Nanosize, mega-impact, potential for medical applications of nanotechnology. J. Craniofac. Surg. 17: 3-7.

Asharani PV, Hande MP and Valiyaveettil S (2009). Anti-proliferative activity of silver nanoparticles. BMC Cell Biol. 10: 65 .

Bender AR, von Briesen H, Kreuter J, Duncan IB, et al. (1996). Efficiency of nanoparticles as a carrier system for antiviral agents in human immunodeficiency virus-infected human monocytes/macrophages in vitro. Antimicrob. Agents Chemother. 40: 1467-1471.

Celum C, Wald A, Hughes J, Sanchez J, et al. (2008). Effect of aciclovir on HIV-1 acquisition in herpes simplex virus 2 seropositive women and men who have sex with men: a randomised, double-blind, placebo-controlled trial. Lancet 371: 2109-2119.

Celum C, Wald A, Lingappa JR, Magaret AS, et al. (2010). Acyclovir and transmission of HIV-1 from persons infected with HIV-1 and HSV-2. N. Engl. J. Med. 362: 427-439.

Corey L, Wald A, Patel R, Sacks SL, et al. (2004). Once-daily valacyclovir to reduce the risk of transmission of genital herpes. N. Engl. J. Med. 350: 11-20.

Elechiguerra JL, Burt JL, Morones JR, Camacho-Bragado A, et al. (2005). Interaction of silver nanoparticles with HIV-1. J. Nanobiotechnol. 3: 6.

Freeman EE, Weiss HA, Glynn JR, Cross PL, et al. (2006). Herpes simplex virus 2 infection increases HIV acquisition in men and women: systematic review and meta-analysis of longitudinal studies. AIDS 20: 73-83.

Gupta R, Wald A, Krantz E, Selke S, et al. (2004). Valacyclovir and acyclovir for suppression of shedding of herpes simplex virus in the genital tract. J. Infect. Dis. 190: 1374-1381.

Katakowski JA and Palliser D (2010). siRNA-based topical microbicides targeting sexually transmitted infections. Curr. Opin. Mol. Ther. 12: 192-202.

Looker KJ, Garnett GP and Schmid GP (2008). An estimate of the global prevalence and incidence of herpes simplex virus type 2 infection. Bull World Health Organ. 86: 805-12, A.

Mertz GJ, Jones CC, Mills J, Fife KH, et al. (1988). Long-term acyclovir suppression of frequently recurring genital herpes simplex virus infection. A multicenter double-blind trial. JAMA 260: 201-206.

Morris SR, Bauer HM, Samuel MC, Gallagher D, et al. (2008). Neonatal herpes morbidity and mortality in California, 1995-2003. Sex. Transm. Dis. 35: 14-18.

Reitano M, Tyring S, Lang W, Thoming C, et al. (1998). Valaciclovir for the suppression of recurrent genital herpes simplex virus infection: a large-scale dose range-finding study. International Valaciclovir HSV Study Group. $J$. Infect. Dis. 178: 603-610.

Rogers JV, Parkinson CV, Choi YW and Speshock JL (2008). A preliminary assessment of silver nanoparticle inhibition of monkeypox virus plaque formation. Nanoscale Res. Lett. 3: 129-133.

Schrand AM, Braydich-Stolle LK, Schlager JJ, Dai L, et al. (2008). Can silver nanoparticles be useful as potential biological labels? Nanotechnology 19: 235104.

Sondi I and Salopek-Sondi B (2004). Silver nanoparticles as antimicrobial agent: a case study on E. coli as a model for Gram-negative bacteria. J. Colloid Interface Sci. 275: 177-182.

Sondi I, Goia DV and Matijevic E (2003). Preparation of highly concentrated stable dispersions of uniform silver nanoparticles. J. Colloid Interface Sci. 260: 75-81.

Wald A, Zeh J, Barnum G, Davis LG, et al. (1996). Suppression of subclinical shedding of herpes simplex virus type 2 with acyclovir. Ann. Intern. Med. 124: 8-15.

Watson-Jones D, Weiss HA, Rusizoka M, Changalucha J, et al. (2008). Effect of herpes simplex suppression on incidence of HIV among women in Tanzania. N. Engl. J. Med. 358: 1560-1571.

$\mathrm{Xu}$ F, Sternberg MR, Kottiri BJ, McQuillan GM, et al. (2006). Trends in herpes simplex virus type 1 and type 2 seroprevalence in the United States. JAMA 296: 964-973. 